\author{
연부조직에 발생한 로사이-돌프만 병 \\ 송승언 ${ }^{1}$, 임태원 ${ }^{1}$ 이광재, 조아라 ${ }^{1}$, 채병도 $^{2}$, 고명주 $^{3}$, 이채원 $^{3}$ \\ 대동병원 내과 ${ }^{1}$, 외과 ${ }^{2}$, 병리과 $^{3}$
}

\title{
Rosai-Dorfman disease of soft tissue
}

\author{
Seung Eon Song ${ }^{1}$, Tae Won Lim¹, Kwang Jae Lee, A Ra Jo', Byung Do Chae ${ }^{2}$, Myung Ju Ko ${ }^{3}$, \\ Chae Won Lee ${ }^{3}$ \\ Departments of ${ }^{1}$ Internal Medicine, ${ }^{2}$ General Surgery, and ${ }^{3}$ Pathology, Dae Dong Hospital, Busan, Korea
}

\begin{abstract}
Rosai-Dorfman disease (RDD) is a benign proliferative histiocytic disorder of unknown etiology, which typically manifests as lymphadenopathy and systemic symptoms. Lymph node involvement is typical, but soft tissue RDD without nodal or systemic involvement is extremely rare. We report on a case of soft tissue RDD in a 16-year-old girl with a palpable mass on her buttock. It was firm, mobile, and discrete without tenderness. Excisional biopsy was performed, then RDD was confirmed histologically. RDD is a non-neoplastic disease that should be considered in the differential diagnosis of other soft tissue tumors. While the optimal treatment for extranodal RDD remains controversial, surgical excision is typically curative.
\end{abstract}

Keywords: Rosai-Dorfman disease; Proliferative histiocytic disorder; Emperipolesis

\section{서 론}

로사이-돌프만 병(Rosai-Dorfman disease)은 1969년 처음 보고된 다발성 림프절종대를 특징으로 하는 원인미상의 조직 구증식질환이다[1]. 이 질환은 모든 연령대에서 나타날 수 있으며, 발열과 같은 전신증상과 함께 림프절 종대를 동반하 는 것이 특징이다[1,2]. 주로 림프절을 침범하며 모든 장기를 침범가능 하지만, 연부조직에만 국한하여 발생하는 로사이돌프만 병은 매우 드물게 보고되고 있다. 연부조직에 종괴 형태로 병발하여 완전 절제를 시행한 경우는 국내에 보고된 바가 없다. 이에 저자들은 16 세 여자에서 발생한 림프절 침범 이 없는 연부조직 로사이-돌프만 병을 경험하였기에 흥미롭 고 드문 증례로 생각하여, 문헌고찰과 함께 보고하는 바이다.

Received: July 17, 2014, Revised: August 15, 2014, Accepted: August 25, 2014

Corresponding Author: Seung Eon Song, Department of Internal Medicine, Daedong Hospital, 187 Chungnyeoldaero, Dongnae-gu, Busan 47737, Korea Tel: +82-51-550-9963, Fax: +82-51-553-7575

E-mail: xelloss2015@hanmail.net

\section{증 례}

16세 여자가 둔부에 만져지는 종물을 주소로 내원하였다. 약 1 년 전부터 왼쪽 둔부 외측에서 종물이 만져지기 시작하였 으나 통증을 비롯한 불편감이 없어 별다른 처치 및 진료없이 지내다가 종물의 크기가 커지는 양상을 보여 내원했다. 과거 력, 사회력 및 가족력 상에 특이사항 없었다. 내원시 혈압 $110 / 80 \mathrm{mmHg}$, 맥박수 90 회/분, 호흡수 20 회/분, 체온 $36.8^{\circ} \mathrm{C}$ 였으며, 왼쪽 둔부 외측에 $5 \times 4 \times 2 \mathrm{~cm}, 3 \times 2 \times 1 \mathrm{~cm}$ 가량의 압 통이 없는 비교적 단단한 종괴 2 개가 약 $3 \mathrm{~cm}$ 정도의 거리를 두고 만져졌다. 그 외 전신에 만져지는 덩어리 및 림프절 종대는 관찰되지 않았다.

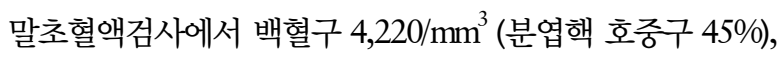
혈색소 $12.6 \mathrm{~g} / \mathrm{dL}$, 혈소판 $267,000 / \mathrm{mm}^{3}$ 였다. 수술 전 시행한 일반혈액검사와 혈청생화학검사에서 모두 정상소견으로 관 찰되었다.

양성 연부조직 종양이 의심되는 소견으로 확진을 위해 절제 생검을 계획하고 시행하였다. 수술 후 출혈 등의 합병증 소견 이 관찰되지 않아 다음날 퇴원하였다. 


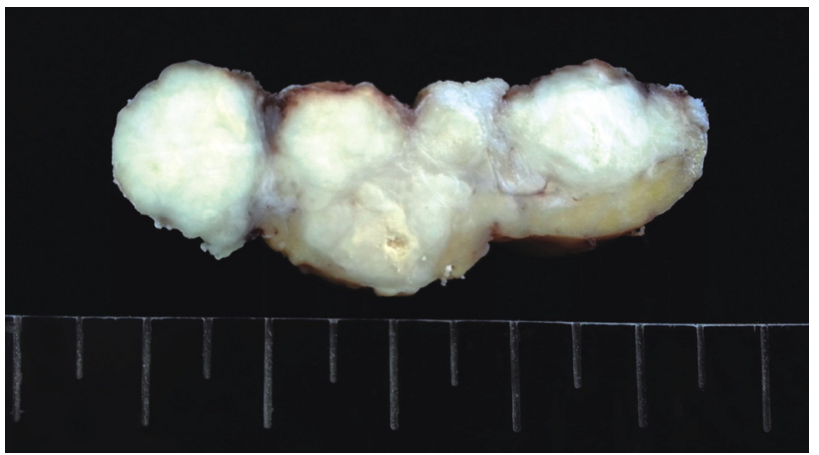

Fig. 1. A whitish tan firm multinodular mass involving soft tissue is observed in the buttock region.
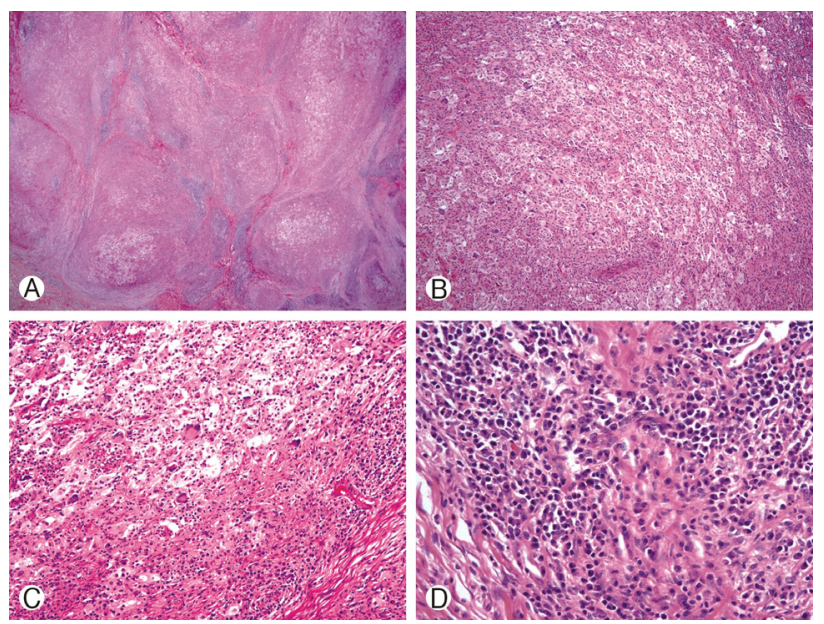

Fig. 2. (A) Low-power view shows nodular appearance with architectural effacement $(\mathrm{H} \& \mathrm{E}$ stain, $\times 20)$. (B, C) High-power view shows numerous histiocytes with multinucleated giant cells and other inflammatory cells $(\mathrm{H} \& \mathrm{E}$ stain, $\mathrm{B} \times 100 ; \mathrm{C} \times 200)$. (D) The aggregation of mature plasma cells is impressive (H\&E stain, $\times 400)$.

절제생검으로 채취한 조직의 육안 소견상 크기는 각각 $5.0 \times 4.0 \times 1.5 \mathrm{~cm}$ (피부 $3.0 \times 0.7 \mathrm{~cm}$ ), $3.0 \times 3.0 \times 1.5 \mathrm{~cm}$ (피부 $2.1 \times 0.3 \mathrm{~cm})$ 로 검체의 절단면은 결절성 형태를 보이고 균일 한 연갈색을 띠었으며, 비교적 단단하였다(Fig. 1). 현미경 소 견상 경계가 불분명한 다결절성 병변에 다수의 조직구 증식 과 함께 염증세포의 침윤이 관찰되었다. 일부의 조직구는 다핵세포의 형태를 보이기도 하였으며, 때때로 이형성을 보 이는 세포도 보였고, 섬유화와 함께 형질세포가 다수 모여있 는 부분도 관찰되었다(Fig. 2). 조직구 세포질 내부에 다수의 림프구가 탐식된 엠페리포레시스(emperipolesis)가 관찰되 었으며, 이는 로사이-돌프만 병의 특징적인 조직소견으로 진 단에 도움이 되었다(Fig. 3).

조직학적으로 로사이-돌프만 병 진단 후 림프절 침범을

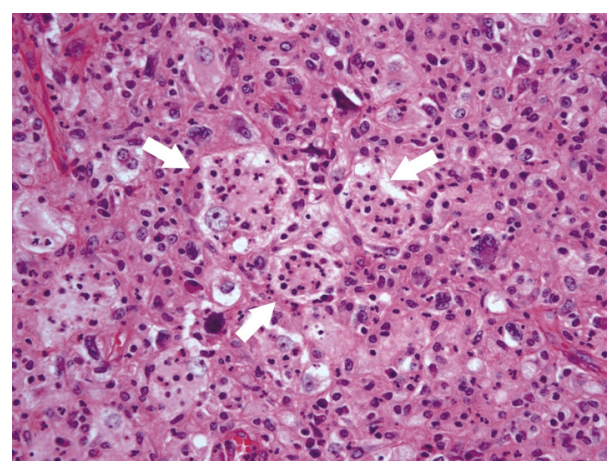

Fig. 3. Many histiocytes have numerous intact inflammatory cells in their cytoplasm (emperipolesis, arrow) (H\&E stain, $\times 400)$.

확인하기 위해 복부 및 골반 컴퓨터단층촬영을 시행하였다. 컴퓨터단층촬영에서 주위 림프절 침범 및 잔여 종괴를 의심 할 만한 소견은 관찰되지 않았다. 현재 3 개월째 외래경과 관찰 중이며, 재발은 보이지 않았다.

\section{고 찰}

로사이-돌프만 병은 광범위 림프절병을 동반한 동 조직구 증(sinus histiocytosis with massive lymphadenopathy)으로 병 리학자인 Rosai와 Dorfman에 의해 처음으로 분류되었다[1]. 초기 보고와는 달리 림프절 이외의 전신장기를 침범할 수 있다는 사실이 밝혀지면서 1988년 이후 로사이-돌프만 병이 라는 용어가 선호되고 있다[3].

로사이-돌프만 병의 림프절외 침범은 $43 \%$ 에서 나타나고, 그 중 연부조직에 발병한 로사이-돌프만 병은 전체의 $3 \%$ 로 매우 드물게 확인되었다[4]. 세계적으로 논문을 통해 보고된 연부조직에만 국한된 로사이-돌프만 병은 1988-2013년까지 68예였으며, 동양인에서 발현빈도가 더 높게 보고되고 있다 [2,5-16].

림프절을 침범하는 경우에는 전신증상 및 혈액학적 이상 을 동반하는 경우가 많지만 연부조직에 국한하여 나타난 경 우에는 전신증상 및 혈액검사에서 이상소견을 동반하지 않 은 경우가 더 많았다[2,6]. 림프절을 주로 침범하는 로사이돌프만 병의 전체 평균 연령은 20.6세이고[4], 연부조직에서 발생한 로사이-돌프만 병의 경우는 46.6세로 더 높은 연령대 에서 발생하였다(Table 1).

지금까지 보고된 연부조직에 국한된 로사이-돌프만 병은 여성에서 호발하였으며(남:여 $=28: 40)$, 연령은 15 세부터 72 세 까지로 평균 연령은 46.6세였다. 한 부위에 국한하여 발생한 경우는 55 예로 $80 \%$ 를 차지하였으며, 두 개 이상의 다발성 
Table 1. Clinical information from published reports on 36 patients with soft tissue Rosai-Dorfman disease

\begin{tabular}{|c|c|c|c|c|c|c|c|}
\hline Study & $\begin{array}{l}\text { No. of } \\
\text { Person }\end{array}$ & Sex & Age & Location & $\begin{array}{l}\text { Presenting } \\
\text { symptoms }\end{array}$ & $\begin{array}{l}\text { Surgical } \\
\text { excision }\end{array}$ & Progress \\
\hline $\begin{array}{l}\text { Suster et al, } \\
1988 \text { [10] }\end{array}$ & 1 & $\mathrm{~F}$ & 72 & $\begin{array}{l}\text { Lateral upper arm, } \\
\text { middle third of thigh }\end{array}$ & $\begin{array}{l}\text { Subcutaneous } \\
\text { nodules }\end{array}$ & No & $7 \mathrm{yr}$, spontaneous resolution \\
\hline $\begin{array}{l}\text { Montgomery et al, } \\
1992 \text { [9] }\end{array}$ & 13 & $\begin{array}{l}\text { F: } 10 \\
\text { M: } 3\end{array}$ & $\begin{array}{l}27-66 \\
\text { (mean: 49) }\end{array}$ & $\begin{array}{l}\text { Extremities: } 7 \text {, trunk: } \\
5 \text {, head and neck: } 1 \text {, } \\
\text { retroperitoneum: } 1\end{array}$ & $\begin{array}{l}\text { Papules and nodules } \\
\text { otherwise not } \\
\text { reported }\end{array}$ & 7 cases & $\begin{array}{l}\text { Mean } 19 \text { mo }(2-52 \mathrm{mo}), 8 \\
\text { cases: no recurrence, } 4 \text { cases: } \\
\text { persistence } \& \text { recurrence, } 1 \\
\text { cases: not reported }\end{array}$ \\
\hline $\begin{array}{l}\text { Govender et al, } \\
1997 \text { [8] }\end{array}$ & 1 & $\mathrm{~F}$ & 34 & Chest wall & Superficial firm mass & Yes & $6 \mathrm{mo}$, no recurrence \\
\hline $\begin{array}{l}\text { Child et al, } \\
1998 \text { [11] }\end{array}$ & 1 & $\mathrm{~F}$ & 36 & Posterior thigh & $\begin{array}{l}\text { Hyperpigmented } \\
\text { plaque; pain }\end{array}$ & No & $12 \mathrm{mo}$, no recurrence \\
\hline $\begin{array}{l}\text { Quaglino et al, } \\
1998 \text { [12] }\end{array}$ & 1 & $\mathrm{~F}$ & 70 & $\begin{array}{l}\text { Skin of arms, face, } \\
\text { buttocks }\end{array}$ & Nodules & $\begin{array}{l}\text { Not } \\
\text { reported }\end{array}$ & Not reported \\
\hline $\begin{array}{l}\text { Huang et al, } \\
2001[13]\end{array}$ & 1 & $\mathrm{~F}$ & 43 & Medial upper arm & $\begin{array}{l}\text { Paresthesia of } \\
\text { forearm }\end{array}$ & Yes & $\begin{array}{l}12 \text { mo, no recurrence, } \\
\text { hypoesthesia on lesion }\end{array}$ \\
\hline $\begin{array}{l}\text { Brenn et al, } \\
2002 \text { [7] }\end{array}$ & 22 & $\begin{array}{l}\text { F: } 14 \\
\text { M: } 8\end{array}$ & $\begin{array}{l}\text { 15-68 } \\
\text { (mean: 43) }\end{array}$ & $\begin{array}{l}\text { Extremities: } 5 \text {, trunk: } \\
14 \text {, head and neck: } 8\end{array}$ & $\begin{array}{l}\text { Papules and nodules; } \\
\text { enlarging lump; pain }\end{array}$ & 6 cases & $\begin{array}{l}\text { Mean } 17 \text { mo }(6-144 \text { mo), } 6 \\
\text { cases: remission, } 7 \text { cases: per- } \\
\text { sistence, } 2 \text { cases: recurrence, } \\
\text { otherwise not reported }\end{array}$ \\
\hline $\begin{array}{l}\text { Kong et al, } \\
2007 \text { [5] }\end{array}$ & 23 & $\begin{array}{l}\text { F: } 8 \\
\text { M: } 15\end{array}$ & $\begin{array}{l}21-70 \\
\text { (mean: 48) }\end{array}$ & $\begin{array}{l}\text { Extremities: } 13 \text {, trunk: } \\
\text { 11, head and neck: } 5\end{array}$ & $\begin{array}{l}\text { Papules and nodules; } \\
\text { tenderness; subcuta- } \\
\text { neous mass; fever; } \\
\text { pruritus }\end{array}$ & 8 cases & $\begin{array}{l}\text { Mean } 20 \text { mo }(2-55 \mathrm{mo}), 8 \\
\text { cases: no recurrence, } 6 \text { cases: } \\
\text { remission, } 6 \text { cases: persistence } \\
\& \text { recurrence, } 3 \text { cases: not } \\
\text { reported }\end{array}$ \\
\hline $\begin{array}{l}\text { Potts et al, } \\
2008 \text { [14] }\end{array}$ & 1 & $\mathrm{~F}$ & 31 & Right forearm & $\begin{array}{l}\text { Firm, hyperpigmen- } \\
\text { ted mass }\end{array}$ & Yes & $3 \mathrm{mo}$, no recurrence \\
\hline $\begin{array}{l}\text { Molina-Garrido et al, } \\
2011 \text { [15] }\end{array}$ & 1 & M & 43 & $\begin{array}{l}\text { Parieto-occipital } \\
\text { cutaneous lesion }\end{array}$ & $\begin{array}{l}\text { Red-yellow nodule, } \\
\text { pain in inferior } \\
\text { maxillary area }\end{array}$ & Yes & 3 mo, no recurrence \\
\hline $\begin{array}{l}\text { Shi et al, } \\
2011 \text { [16] }\end{array}$ & 1 & $\mathrm{~F}$ & 45 & $\begin{array}{l}\text { Face, neck, } \\
\text { extremities }\end{array}$ & $\begin{array}{l}\text { Papulonodular } \\
\text { plaques }\end{array}$ & No & $5 \mathrm{wk}$, partial regression \\
\hline $\begin{array}{l}\text { Komaragiri et al, } \\
2013 \text { [6] }\end{array}$ & 1 & $\mathrm{~F}$ & 56 & $\begin{array}{l}\text { Right medial thigh; } \\
\text { left medial thigh }\end{array}$ & $\begin{array}{l}\text { Enlarging mass; knee } \\
\text { joint pain }\end{array}$ & Yes & $\begin{array}{l}9 \text { mo, no recurrence on right } \\
\text { but new lesion on left }\end{array}$ \\
\hline Our case & 1 & $\mathrm{~F}$ & 16 & Left buttock & Enlarging mass & Yes & $3 \mathrm{mo}$, no recurrence \\
\hline
\end{tabular}

병변으로 나타난 경우는 13예로 나타났다. 총 병변의 수는 83 개로 발생부위는 몸통(33예, 40\%), 상하지(32예, 39\%), 두경부(17예, 20\%), 후복막(1예, 1\%) 순으로 확인되었으며, 발열과 같은 전신증상은 7예에서 보고되었다(Table 1). 본 증례의 경우, 다른 증례와 비교하여 연령이 낮으므로 앞으로 림프절 침범여부에 대한 지속적인 경과관찰이 필요할 것으 로 생각된다.

로사이-돌프만 병의 병인은 아직 밝혀지지 않았다. 감염이 나 염증성 질환과 연관되어 감염성 병원체가 원인이 될 것으 로 주장하는 설이 있고, 종괴를 형성하는 경향 때문에 종양성 질환이라는 주장도 있으며, 자가면역질환과 동반되어 나타나 는 경우가 있어 면역학적 질환으로 간주되기도 한다[2,6,8].
면역글로불린G4 (IgG4)-양성세포의 증식이 관찰되어 최근 에는 IgG4-관련 질환과의 관련성에 대해 논의되고 있다[17]. 로사이-돌프만 병은 림프절종대를 동반할 경우 모든 림프 증식성 질환을 감별하여야 하며, 본 증례와 같이 림프절외 조직을 침범할 경우, 각각의 부위에 종괴를 형성할 수 있는 모든 질환을 감별해야 한다. 하지만 매우 드문 질환으로 조직 학적 확인 전에는 이 질환을 의심하기가 쉽지 않다. 본 증례 의 경우에서도 임상 및 육안소견으로는 감별이 어려웠으며, 조직학적으로 엠페리포레시스가 다수 관찰되어 확진할 수 있었다. 이는 진단에 가장 특이적인 소견으로 림프구가 효소 에 의해 공격받지 않고 세포질 내에서 온전하게 관찰되어 식세포작용과 구분된다. 종종 적혈구와 같은 면역외 세포 
또한 조직구 세포질 안에서 관찰되기도 한다. 림프절 이외의 조직에서 병발했을 경우 엠페리포레시스는 두드러지지 않고 이차적인 콜라겐 침착이 우세하게 나타나는 경우도 있으며, 이러한 경우에는 진단에 어려움이 있으므로 면역화학염색 등의 도움이 필요하다[2]. 면역화학염색상 연부조직 로사이돌프만 병의 $94.4 \%$ 에서 S- 100 단백질에 양성소견을 보이며, 이외에도 $\alpha 1$-antichymotrypsin, CD-68과 CD-1a에 양성을 보일 수 있다[2,4,6].

로사이-돌프만 병은 병의 경과를 예측하기 어려우나 이 질환이 직접적인 원인이 되어 사망하는 경우는 매우 드물며, $90 \%$ 까지 자연관해를 보이므로 특별한 증상이 없다면 경과 관찰이 가능하다. 광범위한 림프절을 침범한 경우, 다발성 병변을 보이는 경우, 신장, 간 및 호흡기계와 같은 주요 장기 를 침범한 경우, 그리고 혈액학적 이상과 면역학적 결핍이 동반되었을 때 불량한 예후를 보인다[2,18]. 하지만 본 증례 와 같이 연부조직에 국한하여 나타난 경우에서는 예후가 매우 좋은 것으로 관찰되었다[5,6] (Table 1).

드물게 스테로이드, 항암제, 항결핵제, 항바이러스제, 방 사선치료 등의 다양한 치료가 시도되고 있으나, 진행성 경과 및 중요 임상증상을 동반할 경우, 그리고 다른 질환과의 감별 을 위해 수술적 절제를 시행할 수 있으며, 진단과 치료에 있어서 가장 적절한 치료로 사료된다[3,18].

\section{REFERENCES}

1. Rosai J, Dorfman RF. Sinus histiocytosis with massive lymphadenopathy. A newly recognized benign clinicopathological entity. Arch Pathol 1969;87:63-70.

2. Rosai J. Rosai and Ackerman's surgical pathology. 10th ed. Edinburgh; New York: Mosby; 2011. p.1801-3, 2192-3.

3. Foucar E, Rosai J, Dorfman RF. Sinus histiocytosis with massive lymphadenopathy. Current status and future directions. Arch Dermatol 1988;124:1211-4.

4. Foucar E, Rosai J, Dorfman R. Sinus histiocytosis with massive lymphadenopathy (Rosai-Dorfman disease): review of the entity. Semin Diagn Pathol 1990;7:19-73.

5. Kong YY, Kong JC, Shi DR, Lu HF, Zhu XZ, Wang J, et al. Cutaneous rosai-dorfman disease: a clinical and histopatho- logic study of 25 cases in China. Am J Surg Pathol 2007;31: 341-50.

6. Komaragiri M, Sparber LS, Santos-Zabala ML, Dardik M, Chamberlain RS. Extranodal Rosai-Dorfman disease: a rare soft tissue neoplasm masquerading as a sarcoma. World J Surg Oncol 2013;11:63.

7. Brenn T, Calonje E, Granter SR, Leonard N, Grayson W, Fletcher CD, et al. Cutaneous rosai-dorfman disease is a distinct clinical entity. Am J Dermatopathol 2002;24:385-91.

8. Govender D, Chetty R. Inflammatory pseudotumour and Rosai-Dorfman disease of soft tissue: a histological continuum? J Clin Pathol 1997;50:79-81.

9. Montgomery EA, Meis JM, Frizzera G. Rosai-Dorfman disease of soft tissue. Am J Surg Pathol 1992;16:122-9.

10. Suster S, Cartagena N, Cabello-Inchausti B, Robinson MJ. Histiocytic lymphophagocytic panniculitis. An unusual extranodal presentation of sinus histiocytosis with massive lymphadenopathy (Rosai-Dorfman disease). Arch Dermatol 1988; 124:1246-9.

11. Child FJ, Fuller LC, Salisbury J, Higgins EM. Cutaneous Rosai-Dorfman disease. Clin Exp Dermatol 1998;23:40-2.

12. Quaglino P, Tomasini C, Novelli M, Colonna S, Bernengo MG. Immunohistologic findings and adhesion molecule pattern in primary pure cutaneous Rosai-Dorfman disease with xanthomatous features. Am J Dermatopathol 1998;20:393-8.

13. Huang HY, Liang CL, Yang BY, Sung MT, Lin JW, Chen WJ. Isolated Rosai-Dorfman disease presenting as peripheral mononeuropathy and clinically mimicking a neurogenic tumor: case report. Surg Neurol 2001;56:344-7.

14. Potts CA, Bozeman AP, Walker AN, Floyd WE 3rd. Cutaneous Rosai-Dorfman disease of the forearm: case report. J Hand Surg Am 2008;33:1409-13.

15. Molina-Garrido MJ, Guillén-Ponce C. Extranodal rosai-dorfman disease with cutaneous and periodontal involvement: a rare presentation. Case Rep Oncol 2011;4:96-100.

16. Shi XY, Ma DL, Fang K. Cutaneous Rosai-Dorfman disease presenting as a granulomatous rosacea-like rashs. Chin Med J (Engl) 2011;124:793-4.

17. Menon MP, Evbuomwan MO, Rosai J, Jaffe ES, Pittaluga S. A subset of Rosai-Dorfman disease cases show increased IgG4-positive plasma cells: another red herring or a true association with IgG4-related disease? Histopathology 2014;64: 455-9.

18. Pulsoni A, Anghel G, Falcucci P, Matera R, Pescarmona E, Ribersani M, et al. Treatment of sinus histiocytosis with massive lymphadenopathy (Rosai-Dorfman disease): report of a case and literature review. Am J Hematol 2002;69:67-71. 